\title{
Seasoned Equity Issues in a Closely Held Market: Evidence from France
}

\author{
Jean-François GAJEWSKI (IRG, ESA, University of Paris-XII) \\ Edith GINGLINGER (DRM-Cereg, University Paris-Dauphine)*
}

JEL Classification: G32, G14 and D80.

Key words: seasoned equity issues, flotation methods, ownership structure.

First version: January 1998; this version: March 2002.

- Corresponding author : University Paris-Dauphine, place du maréchal de Lattre de Tassigny, 75775Paris cedex 16. E-mail : edith.ginglinger@dauphine.fr

- We are grateful to Pierre-Henri Chaix for providing data from the "Européenne des données ". We would like to thank all the participants at the 1998 conference of the European Financal Management Association in Lisbon, at the 1998 conference of the French Finance Association in Lille, at the 1998 conference of the Northern Finance Association in Toronto and at the 1998 conference on "Raising Capital in Different National Markets" in Frankfurt. We appreciate the helpful comments from Espen Eckbo and an anonymous referee. Research support from the CNRS (Centre National de la Recherche Scientifique) under grant is also gratefully acknowledged. This paper was previously entitled "The information content of equity issues in France". 


\begin{abstract}
This paper examines seasoned equity offerings in France. Even though a rights offering is the primary flotation method, French companies are increasingly using the relatively expensive public offering method. We show that the market reaction to the announcement of seasoned equity issues is significantly negative for rights issues and insignificantly negative for public offerings. Our results suggest that the adverse selection effect is greater for rights issues than for public offerings, due to stronger underwriter certification for the public offerings. We find that the share price effect is positively related to blockholders take-up renouncements for firms with prior concentrated ownership. For these firms, the favourable ownership dispersion effect offsets the adverse selection effect.
\end{abstract}




\section{Introduction}

Despite the lower flotation costs of rights issues, most U.S. firms choose public offerings to raise capital. This puzzling evidence is often referred to as the equity financing paradox. Several explanations have been put forward to explain this paradox, which suggest that rights offerings may be more expensive in other ways. These explanations include capital gains taxes (Smith, 1977), shareholder selling costs (Hansen, 1988), differences in prior share ownership (Hansen and Pinkerton, 1982) and adverse selection costs (Eckbo and Masulis, 1992). ${ }^{1}$ The purpose of this study is to provide new international evidence on the valuation effects and the costs associated with alternative flotation methods.

The relative frequencies of rights issues and public offerings differ strongly across countries. For example, in the U.S., the overwhelming majority of corporations choose the firm commitment underwriting method. In Japan, according to Kang and Stulz (1996), 66\% of the common stock offerings over the period 1985-1991 were public offerings. In most European countries and in Australia, rights issues are the primary flotation method. ${ }^{2}$ In contrast to the U.S. results, several studies find a positive or a non-negative stock price reaction to the announcement of equity offerings in these countries.

In this paper, we investigate seasoned equity offerings in France, where rights issues represented 90\% of all common stock offerings over the period 1986-1996. Our sample includes uninsured rights, rights with standby underwriting and public offerings.

1 For a review, see Eckbo and Masulis (1995).

2 See Loderer and Zimmerman (1987) for Switzerland, Hietala and Löyttyniemi (1991) for Finland, Bohren, Eckbo and Michalsen (1997) for Norway and Slovin, Sushka and Lai (2000) for the U.K.. 
Throughout the paper, we refer to issues without rights as public offerings. The French market has some distinctive characteristics, which motivate this study. While a rights offering is the primary flotation method in France, French firms select the public offering method more frequently than in other European equity markets. French firms relied on rights offerings almost exclusively until 1985. But this has changed recently, with the proportion of public offerings increasing from 4.84\% over the 1986-1989 period to $16.84 \%$ over the $1990-1996$ period. ${ }^{3}$ We examine the evidence on flotation costs, and confirm the existence of an equity financing paradox in France. The growing preference for the more expensive public offering method is documented and potential explanations are examined.

We investigate the market reactions to several categories of equity issue announcements in France. We also examine the determinants of the market reaction to these issue announcements by means of cross-sectional regressions. Our results indicate that rights offerings by French firms lead to a more negative signal of share value than do public offerings. For the 1986-1996 period, we find significant two-day average excess returns of $-0.74 \%$ for standby rights issues and $-1.11 \%$ for uninsured rights. Public offerings generate an insignificant negative return. Further, when we look at the more recent 1990-1996 period, we find significant two-day average excess returns of $1.28 \%$ for standby rights issues, $-2.84 \%$ for uninsured rights, and an insignificant negative return for public offerings. Our results suggest that the choice of a rights issue in France should be seen as a more negative signal of share value, especially in the more recent period.

3 This proportion is even larger and reaches about 50\% when we consider the period 1997-1999, which is not included in our sample. During the whole period, the public offering flotation method was often chosen by French firms for their issues of units of common stocks and warrants. These issues are not included in the study, because they behave differently. 
The offer price for French public offerings is determined four days on average before the beginning of the issue period. Further, the issue price is subject to regulatory constraints. These constraints increase the risk for the underwriter, who will only agree to underwrite the public offering if he assesses that the stock's fundamental value is higher than the offer price. We argue that French public offerings are characterised by stronger underwriter certification and monitoring than U.S. firm commitments and that this may reduce the adverse selection effect. Our evidence can be compared to the results of Cooney, Kato and Schallheim (1997) who find a positive abnormal return on the announcement date of Japanese firm commitments and to the results of Slovin, Sushka and Lai (2000) who find a significant positive announcement return for U.K. placings.

Further, we find that the announcement effect of seasoned equity offerings is (i) more negative when the issue size is large and the preannouncement abnormal performance of the stock is high, and (ii) more positive when the gross proceeds of the issue are used to finance an acquisition or an investment.

We focus on differences in corporate control motives that may explain the choice between alternative flotation methods, and provide evidence on the effects of blockholders ${ }^{4}$ renouncing their rights to purchase shares. The French equity market, like most European equity markets, is dominated by closely held firms. Hansen and Pinkerton (1982) argue that firms with concentrated share ownership will choose rights issues. Consistent with that argument, we find that the percentage of shares held by the main shareholder in France is significantly greater for rights offers.

4 We call blockholders all the shareholders who hold more than $5 \%$ of the shares at the date of the issue and whose name is given in the COB registration prospectus. 
In France, the blockholders must disclose in the issue prospectuses their intention to subscribe or to renounce their new share allocation. Our evidence shows that share allocations not taken up by blockholders are much larger for underwritten public offerings than for rights and standby offerings. This is consistent with the Eckbo and Masulis (1992) results, who show that rights offerings become more costly and less attractive as take-up by current shareholders falls. In their model, the issuing firms show adverse selection to a degree that, all else being equal, is inversely related to the current shareholder take-up. Then, the market reaction should be negatively related to the shareholder take-up. Our evidence confirms this prediction for the firms that are not closely held by a controlling shareholder. ${ }^{5}$ For the closely held firms, blockholders take-up renouncements are favourable news for external investors, which positively affects the market reaction. We conjecture that increasing ownership dispersion enhances share value for these firms, by increasing incentives for management monitoring and especially by attenuating conflicts of interest between majority and minority shareholders. The likelihood of tunneling (transfer of resources out of the company to its controlling shareholder), which is frequently a problem in civil-law countries, such as France (see, for instance, Johnson et al. 2000), could be particularly reduced.

We also report that public offerings are generally characterized by strong underwriter certification due to high risk born by underwriters, especially when there are large renouncements by blockholders. This certification may more than offset the greater adverse selection costs associated with public issues and explain the lack of market reaction at the announcement of a public issue.

5 A controlling shareholder is a shareholder who holds more than $50 \%$ of the shares on the date of the issue. 
The paper proceeds as follows. In section 2, the characteristics of French seasoned equity offerings are described. In section 3, we give evidence on flotation costs. Section 4 shows evidence on the valuation effect of offering announcements. Section 5 puts forward factors explaining market reaction on the date of announcement. The summary and conclusions are given in section 6 .

\section{Institutional framework and data}

\subsection{The French institutional setting}

A seasoned equity offering has to be approved at an extraordinary general shareholders' meeting. All decisions at the extraordinary general shareholders' meeting need a majority of $66.6 \%$ of the voting rights. ${ }^{6}$ French law grants shareholders a right to purchase new shares, but the extraordinary general shareholders’ meeting may waive this pre-emptive right. Approval for an issue may be given for a maximum amount to be raised within five years (rights), three years (without rights) or 26 months (when the type of security and flotation method is not specified). Pre-emptive rights cannot be permanently waived by means of charter amendment.

The French institutional setting for public offerings differs from the U.S. setting in three ways. First, shares are initially offered to current shareholders on a pro-rata basis, for ten days on average, but this purchase priority cannot be traded like a right. ${ }^{7}$

6 Decisions made during a general shareholders' meeting require a majority of $50 \%$ of the voting rights. Extraordinary general shareholders' meetings are required to alter the charter.

7 Under these conditions, at first glance, outside investors can subscribe only to the part of the issue that is not reserved for current shareholders. Nevertheless, if current shareholders do renounce their allocation, the initial part offered to external investors can be increased. The rate of increase depends on shareholders' renouncements. 
Secondly, there is a regulatory constraint on the issue price. Thirdly, public offerings are generally underwritten through a standby-underwriting contract.

In French public offerings, the offer price and the size of the issue are decided on the most recent $\mathrm{COB}$ date, ${ }^{8}$ which is on average four days before the beginning of the issue period. The underwriter incurs the risk of adverse changes in share prices from the COB date to the end of the average ten-day priority period. In the U.S. firm commitment method, the offer price is set the day before the public offering date and the offering is very short, usually just a few hours. The French constraints on the issue price increase the risk for the underwriters, who will only underwrite a public offering if their assessment of the true value of the stock is higher than the offer price. The existence of a priority period for current shareholders increases the underwriter's risk by postponing the end of the issue period. As a result, underwriter certification in French public offerings may be stronger than in U.S. firm commitments. From the perspective of the Bohren, Eckbo and Michalsen (1997) model, underwriters of French public offerings may be effective monitors: overvalued firms may be forced to choose rights issues or uninsured public offerings.

\subsection{Equity issues in France over the period 1986-1996}

All equity issues taking place in the French market can be identified through the annual reports of the COB. Empirical tests are run for offers made over the 1986-1996 period. Prices are extracted from the Euronext database. In our initial sample, 590 equity issues from 1986 to 1996 are examined and classified by their characteristics. The final sample excludes all issues that do not meet the following criteria: 
- The issue involves a single type of security and does not come with a stock dividend; units of common stock and warrant offerings are excluded as well;

- The issue does not involve a common stock reduction or a restructuring plan;

- The firm does not make important new releases, such as earnings, at the time of the issue announcement. ${ }^{9}$

These criteria produce a sample of 219 offerings described in table 1, of which 90\% are rights issues and 10\% are public offerings. In France, most seasoned equity issues, whether rights or not, are underwritten.

\section{[Insert table 1]}

Table 2 describes the characteristics of the sample. The characteristics of the new issues are reported in the registration statement filed with the COB and include offering proceeds, subscription price, number of current shares, underwriters' name and shareholdings. The company also provides an estimate of the flotation costs.

\section{[Insert table 2]}

The average size of an equity rights offering is 351 million FF and the average size of a public offering is 1241 million FF. On average, the subscription price is $80 \%$ of the prevailing stock price (78\% for rights issues and 95\% for public offerings). French firms

8 The COB (Commission des Opérations de Bourse) plays the same role as the SEC in the US.

9 French firms quite often announce equity issues at the same time, or immediately after earnings publications. This evidence is consistent with Korajczyk, Lucas and McDonald (1991), who find that equity issues follow shortly after earnings publications. 
are required to fix the rights subscription price at the agreement date, which is on average 10 days before the beginning of the subscription period. The subscription period lasts for 15 days on average. The subscription price in public offerings is set nearer to the beginning of the issue period (on average 4 days before), and the subscription period is shorter (on average 8 days). This relatively early price setting date in France compared to the U.S. explains why the issuer and the underwriter put more effort into anticipating the secondary market price when setting the offer price. The average number of shares offered, as a percentage of outstanding and new shares, is $23.47 \%$ ( $24.12 \%$ for rights issues and $17.73 \%$ for public offerings). It is interesting to note that the choice of flotation method varies from country to country though it is influenced by the size of firms. For instance, in the U.K., according to Slovin, Sushka and Lai (2000), firms that choose placings are very small relative to rights issuers. In the U.S., uninsured rights issuers are small firms, but no significant difference in issuer size appears between standby rights issuers and firm commitments issuers (Eckbo and Masulis, 1992). In France, large firms prefer public offers to standby rights, which, in turn, are preferred to uninsured rights.

\subsection{Ownership structure and expected shareholder take-up}

Hansen and Pinkerton (1982) show that U.S. firms with more concentrated share ownership tend to choose rights issues. Bohren, Eckbo and Michalsen (1997) show that in Norway, the average percentage of outstanding equity held by the 20 largest shareholders varies from 54\% over the $1980-1984$ period to $61 \%$ over the $1985-1993$ period. They find little evidence that the average ownership characteristics vary systematically by flotation method. In table 3, we show that the percentage of shares 
held by the main shareholder in France is significantly lower for the underwritten public offerings compared to alternative flotation methods (29.78\% versus $47.32 \%)$. The major blockholders are financial institutions (36.1\% of offerings), a family or an individual investor (16.4\% of offerings), another firm (42\% of offerings) and the state (1.8\% of offerings). Only four offerings in our sample involve privatization activities. We checked that these issues do not behave differently to non-privatization SEOs. The percentage of shares held by blockholders before the offering exceeds $50 \%$ regardless the flotation method, and stays above 50\% after the offering. For rights issues (public offerings) this percentage is $65.17 \%$ (57.35\%) before and $62.94 \%$ (55.57\%) after the offering.

\section{[Insert table 3]}

As highlighted by Eckbo and Masulis (1992), current shareholder demand for new equity offerings plays an important role in the decision on flotation method. Managers expecting low shareholder participation select firm commitments. Firms with a high (medium) expected shareholder take-up choose uninsured rights (standby rights).

Our evidence shows that, on average, $28.8 \%$ of the issues lead to blockholder renouncements, either total or partial. The share allocation not taken up by blockholders, when different from zero, averages $62.53 \%$ for underwritten public offerings and $33.67 \%$ for other flotation methods. The percentage of the issue offered to external investors is largest for underwritten public offerings (62.9\%), followed by standby rights issues (46.9\%) and finally uninsured rights offerings (37.9\%). Uninsured issues, whether rights or public offerings, display large shareholder precommitments: 
blockholders offer their guarantee for all or part of the issue and in this way substitute bank underwriting. The evidence is consistent with the results of Eckbo and Masulis (1992).

Despite blockholder renouncements, the average percentage of shares held by blockholders remains above 50\% after the equity offering. ${ }^{10}$ Hostile takeovers are therefore very difficult unless one or more blockholders participate. Increased shareholder dispersion may not lead to disciplinary effects, because ownership remains concentrated, on average, after the offering. However, even if all the blockholders together own a large part of the shares after the offering, the controlling shareholder may own less than 50\%. Moreover, in France, some decisions require a majority of $66.6 \%$ of share voting to be approved, which is less likely after an equity offering with blockholder renouncements.

\section{Evidence on flotation costs}

Table 2 shows average relative costs for the different flotation methods. The French flotation costs seem much lower in relative value than those reported by Slovin, Sushka and Lai (2000) for U.K. issues or Eckbo and Masulis (1995) for U.S. offerings. These authors show that the direct flotation costs of public underwritten offerings are over $6 \%$ of the issue proceeds, but only $4 \%$ for standby rights offerings and $2 \%$ for uninsured rights offerings. However, our results are very similar to Singh’s (1997) findings for

10 For instance, suppose that blockholders hold $60 \%$ of the shares and decide to subscribe to $50 \%$ of their subscription rights. If the percentage of change in shares is $25 \%$, then blockholders still own $52.5 \%$ of the shares after the equity offering. 
U.S. rights issues: he reports an average underwriting fee of $1.44 \%$ and other expenses of $1.02 \%$ of the gross proceeds. In France, the part of the offering subscribed to by outside investors, which is the most costly part of the issue, is much lower than in the United States. When we consider the total flotation costs as a percentage of the public gross proceeds, that is, the part of the offering not taken up by the main shareholders of the firm, the figures are much closer to the U.S. data.

The results of U.S. studies show that flotation costs are higher for firm commitments, even after checking for the issue characteristics (see, for instance, Eckbo and Masulis, 1995). Public offerings are also more expensive than rights issues in France. We compare flotation costs for the two flotation methods after checking for the issue and firm characteristics. Table 4 shows the coefficient estimates in cross-sectional regressions on the issue characteristics.

\section{[Insert table 4]}

The regression intercept is positive and significant, which indicates a fixed component of flotation expenses. Our results show that the costs of public offerings are significantly higher than those of rights issues. The equity financing paradox is therefore confirmed in France: a growing proportion of French firms issuing common stock choose the relatively more expensive public offering method over the less expensive rights method.

The flotation costs, in relative value, decrease with the gross proceeds of the offer, as a result of economies of scale, and increase with the percentage of the offering that is underwritten. The costs increase with the percentage of the issue not taken up by 
blockholders: the administrative costs and the banking costs are higher for issues where a large fraction is offered to the public. Finally, the flotation costs were lower during the 1990-1996 period. Until the mid-eighties, flotation fees, and especially underwriting fees, were set at a virtually fixed percentage of the gross proceeds $(2.5 \%$ for the underwriting fees) with underwriters compensated only marginally for the different levels of offering risk. The growing competition among banks due to regulatory changes and the privatisation of several banks caused flotation costs to decrease over time.

\section{Valuation effects of equity offering announcements}

Stock price reaction to seasoned equity offerings made by U.S. firms has been extensively examined. A large number of studies of US seasoned equity offerings show that announcements are associated with a decrease in the stock price of firms, especially for firm commitments. For example, Asquith and Mullins (1986) and Eckbo and Masulis (1992) show that share prices of industrial issuers decrease by 3\% over the twoday announcement period. ${ }^{11}$ In other countries, less evidence exists on the valuation effect of equity issues announcements. In Japan, for instance, Kang and Stulz (1996) report a significantly positive reaction of $0.45 \%$ on the announcement of public offerings. In most European countries, empirical studies on issue announcements find positive or insignificant negative market reactions, e.g., $+1.55 \%$ (standby rights) and $+0.23 \%$ but insignificant (uninsured rights) in Norway (Bohren, Eckbo and Michalsen, 1997) and $+0.64 \%$ for rights issues for non financial firms in Germany (Gebhardt and Heiden, 1998). According to Slovin, Sushka and Lai (2000), there is a negative announcement effect for British rights offerings (-2.9\%), but a positive effect $(+3.3 \%)$

11 For a survey of market reactions to equity issue announcements see Eckbo and Masulis (1995). 
for placings, a distinct offering method with few similarities to U.S. firm commitments. These different findings seem puzzling. We shall try to explain them by examining the importance of bank certification and corporate control.

\subsection{Event-study methodology}

A standard event-study is performed in order to measure the average impact on French stock prices of seasoned equity offering announcements, where day 0 is the announcement date. If $R_{i t}$ is the observed logarithmic return for security $i$ and $R_{m t}$ the market index return at date $t, 12$ the excess return can be calculated by the difference between $R_{i t}$ and a benchmark period return $N_{i t}$, which corresponds to a stock's normal daily return in the absence of any event. Three benchmark returns are used: the market index return, the stock's mean return measured over an estimation period prior to the event period and the market-adjusted stock return. The parameters ${ }^{13}$ are estimated over event days - 220 through - 21 days before the announcement $(t=0)$. The crosssectional mean excess return $\left(R A M_{t}\right)$ is then calculated for each event date over 40 days around the announcement date. In order to know if mean excess returns are significantly different from 0 , the null hypothesis $\left(H_{0}: R A M_{t}=0\right)$ is tested. Two parametric tests are

12 The market index return used is the SBF (Société des Bourses Françaises) index that is calculated over the 250 most liquid securities in the Paris market. The index return takes into account the reinvestment of dividends.

13 In the case of the market-adjusted return, the coefficients are estimated by using the OLS values over the estimation period. However, because of non-synchronous trading, OLS estimates are inconsistent. Dimson (1979) proposed a methodology that takes this bias into account. Scholes and Williams (1977) and Fowler and Rorke (1983) have also developed estimates that take return autocorrelations into account. These estimates are calculated by considering two lags and two leads. 
reported. ${ }^{14}$ The first is based on a statistic obtained by dividing the mean excess return by a time-series standard deviation.

$$
\begin{aligned}
& T_{t p s}=\frac{R A M_{t}}{\sigma(R A M)} \text { where } \\
& \sigma(R A M)=\sqrt{\frac{1}{199} \sum_{\tau=-21}^{-220}\left(R A M_{t}-\frac{1}{200} \sum_{\tau=-21}^{-220} R A M_{\tau}\right)^{2}} .
\end{aligned}
$$

The second statistic we use is obtained by dividing the mean excess return by a crosssectional standard deviation.

$$
\begin{aligned}
& T_{\text {trans }}=\frac{\sqrt{N} R A M_{t}}{\sigma\left(R A M_{t}\right)} \text { where } \\
& \sigma\left(R A M_{t}\right)=\sqrt{\frac{1}{N-1} \sum_{i=1}^{N}\left(R A_{i t}-R A M_{t}\right)^{2}} .
\end{aligned}
$$

\subsection{Time-line of important dates}

The first announcement date considered is the Board Meeting date when the firm decides to issue equity. At this date, insider trading is possible. The first public announcement of the offering generally comes in the registration statement filed with the COB. No newspapers in France cover equity issues, unlike US financial press. However, we had access to information in the database of the "Européenne des données," which includes all Agence France Presse (AFP) announcements and those of the main French financial newspapers. As a matter of fact, offering announcements by

14 Under normality, $T_{t p s}$ and $T_{\text {trans }}$ are distributed Student with $T-1$ and $N-1$ degrees of freedom. 
the AFP often take place the day before publication in the financial dailies. Most previous studies of securities issues in France analyse the wealth effect at the BALO date, which is the legal announcement date.

The “ Européenne des données ” date (EDD) corresponds to the first mention of the offerings in the press. The EDD date is taken into account only if it is earlier than the COB date and if the announcement contains the main characteristics of the issue (flotation method, size and offer price). Thus, in our study, the announcement date is the earlier of the EDD and the COB dates. ${ }^{15}$

In the case of rights issues, there is a required period of seven calendar days between the BALO date and the issue date. In the case of public offerings, there is no legal period. The issue date is then frequently the same as the BALO date, or even for a few offerings the day before. When there is a priority period (which is the case for 16 out of the 22 public offerings), the subscription period is at least ten days. Figure 1 reports the time-line for these dates. Table 5 reports the characteristics of these different dates in our sample.

\section{[Insert figure 1]}

\section{[Insert table 5]}




\subsection{Valuation effect on the first announcement date (AD)}

The event study is undertaken around two dates (Board Meeting date and the earlier of the COB and the EDD dates). No stock price adjustment was detected at the Board Meeting date for any of our samples. This date is not usually considered as an informative event date. However, Cooney, Kato and Schallheim (1997) use it to study the impact of Japanese equity offering announcements, and find a significantly positive stock price reaction on this date. The lack of price impact at the board meeting date in France may reflect the fact that the offering information does not have to be released before the legal announcements. The COB agreement date seems to be a better announcement date because the information becomes public on this date at the Latest. However, the COB agreement date does not necessarily correspond to the date when the information is released. If the offer is first announced through the “ Européenne des données ", the EDD date is selected as the date of announcement, otherwise the COB date is chosen for the first date of announcement. The tombstones are published in the newspapers only after publication in BALO and refer to the BALO date. Stock price reactions around announcement dates are reported in table 6. ${ }^{16}$

\section{[Insert table 6]}

Table 6 reports the cumulative mean excess return ${ }^{17}$ for the two-day event window $(0,1)$ where 0 is the announcement date of the offering, for the full sample and

16 Over the period studied in this article, there were no issue cancellations after their announcement.

17 Only the abnormal returns estimated with Dimson's (1979) method are put forward. The other results based on the market model (OLS estimates), the index return, and the mean return lead to similar conclusions. Only the test based on a time-series standard deviation is shown. The test based on the cross-sectional standard deviation and the non-parametric test lead to similar results. 
for the sub-period 1990-1996. For the 1986-1996 period, we find a significant two-day average excess return of $-0.74 \%$ for standby rights issues and $-1.11 \%$ for uninsured rights. ${ }^{18}$ Public offerings generate an insignificant and much smaller negative return. When we look at the more recent 1990-1996 period, we find a significant two-day average excess return of $-1.28 \%$ for standby rights issues, of $-2.84 \%$ for uninsured rights, and an insignificant negative return for public offerings.

Due to the small size of the sample of public offerings, table 6 does not distinguish between the issues with and without a priority subscription period for existing shareholders. All uninsured public offerings contain a priority period. Among the 18 underwritten public offerings, 12 have a priority period. We checked that the abnormal return at the announcement does not differ according to whether or not a priority period exists.

Our results for standby rights are comparable to the returns reported in the U.S. by Eckbo and Masulis (1992), $-1.03 \%$, or Singh (1997) of $-1.07 \%$ and in Norway by Bohren, Eckbo and Michalsen (1997), -0.23\%, but less unfavourable than the results reported by Slovin, Sushka and Lai (2000) in the U.K. (-2.9\%). For uninsured rights, we find a more negative price reaction, which appears at variance from the Eckbo and Masulis (1992) prediction that undervalued firms select uninsured rights ${ }^{19}$. We find an insignificant negative wealth effect at the announcement of an underwritten public offering, which differs from the $-3 \%$, reported in the U.S. studies.

The characteristics of the French underwritten public offerings help to explain our results. In the Eckbo and Masulis (1992) model, the underwriters can only partially

\footnotetext{
18 We examine how rights offers differ between cases with blockholder guarantees and those without. We find that the abnormal return on the announcement date is not significantly different with or without blockholder guarantees.

19 However, the institutional details of the French flotation methods are not exactly the same as in the U.S.
} 
certify the firms' quality, which allows for adverse selection effects. However, if the underwriter is viewed by the issuer and the market as effective in terms of detecting overpriced issues, as argued in Bohren, Eckbo and Michalsen (1997), underwritten offerings may have a significantly positive selection effect or at least a non negative effect. Several studies support a certification role for underwriters.

One of the key features of an underwriting contract is the method of determining the offer price. In the U.S. firm commitments, offer prices are set after the initial announcement, usually just before the stock issue is sold to investors. In other countries, the offer price is set several days before the issue date. Lengthening the time period between the determination of the offer price and the issue date increases the likelihood of a decline in stock price and the risk borne by the underwriters. They will only underwrite an offering if they estimate that the true value of the stock is significantly higher than the offer price. ${ }^{20}$ An announcement of an underwritten offering can therefore be accompanied by a positive or non-negative price reaction.

Cooney, Kato and Schallheim (1997) report that Japanese firms choose between two variants of firm commitment contracts. The first is the fixed-price offering, in which the offer price is determined several days before the beginning of the issue. This contract provides a high level of certification and elicits a positive abnormal return on the announcement date. The second contract, the formula-price offering, provides a lower level of certification and results in an insignificant price reaction. In the U.K. placing contract, the offer price is also set at the initial announcement. Slovin, Sushka and Lai (2000) find a significantly positive excess return, and explain this by the high level of certification provided by the placing contract.

20 Due to specifically French regulation contraints, the offer price cannot be set significantly below the stock price, and very large underwriting fees are uncommon in France. 
French underwritten public offerings are also fixed-price contracts. Further, there is a regulatory constraint that requires setting the offer price at least at the average of ten consecutive daily stock prices chosen from the twenty daily prices preceding the issue date. We argue that, like Japanese firm commitments or U.K. placings, French underwritten public offerings are characterised by strong underwriter certification and monitoring that may reduce the adverse selection effect of equity offerings and explain the non negative wealth effect.

\subsection{Average abnormal returns on the issue date (ID)}

To investigate the price reaction at the beginning of the subscription period, we select the first day of issue and the following twenty days. We can safely assume that it is during this period that stockholders in a rights offering decide whether to exercise or to sell their rights. From table 7, we see that the market reaction at the seasoned equity issue date is significantly negative. Most studies find insignificant returns on the issue date for public offerings (see Asquith and Mullins, 1986 or Eckbo and Masulis, 1992). However, Hansen (1988), Eckbo and Masulis (1992), Kang and Stulz (1996) and Singh (1997) find significant negative returns during the rights offer subscription period.

In an efficient market, prices should take into account all the information available the day the offering is announced. Price changes on the issue day are not the result of new information. However, according to some authors (Mikkelson and Partch, 1988 or Korajczyck, Lucas and McDonald, 1992), since the issue can be withdrawn after the announcement, not withdrawing it indicates that the stock remains overvalued despite the negative reaction following the announcement. In France, over the 1986-1996 
period, no offerings were cancelled after registration; consequently, it seems that this explanation is not empirically important.

The other explanations suggested focus on current stockholder and investor behaviour on the completion date. According to Lease, Masulis and Page (1991), as investors buy stock in the primary market, sellers will exceed buyers in the secondary market, bringing prices down at least to the extent of the bid-ask spread. The results presented in table 7 show a negative reaction around the issue date for rights issues. The extent of the negative reactions around the issue date are very similar to the results of Singh (1997) $(-2.18 \%$ over $(-1 ;+5))$ for an underwritten rights issue sample. During the first days after the beginning of the subscription period, current shareholders have to decide whether to exercise or sell their rights. If they are averse to risk, shareholders who want to sell their rights will do so as soon as possible, as long as rights are in the money. Investors who buy the rights will buy stock in the primary market rather than in the secondary market, bringing secondary market prices down. Furthermore, standby underwriters, who have to buy all remaining shares at the end of the subscription period, are allowed to buy rights in the secondary market and to short-sell the stock to hedge their standby risk exposure. This arbitrage activity may also explain the negative price reaction for rights offerings.

Several previous studies show insignificant results for public offerings on the issue date. We find a significant negative abnormal reaction during the days after the beginning of the public offering subscription period. In the French context, current shareholders may often subscribe first during a priority period and public offerings are underwritten through standby contracts. We show that the expected shareholder take-up is low for public offerings. Current shareholders do not subscribe heavily, and outside 
investors can buy shares in the primary market rather than in the secondary market, bringing the stock prices down. We should bear in mind that current shareholders have a priority subscription period, but when the main shareholders' take-up is low, outside investors may also subscribe immediately: issuers rely on information from blockholders concerning their subscription plans to offer part of the issue to investors immediatly. This may explain the similar results for rights and public issues around the issue date.

\section{Cross-sectional analysis of the announcement effect}

A cross-sectional analysis is undertaken in order to explain the magnitude of mean abnormal returns. This analysis makes it possible to observe differences between public issues and rights issues around the date of announcement. The dependant variable is the two-day excess return at the announcement of equity offerings. Several continuous and qualitative variables are included in our analysis.

\subsection{Variable definitions}

The continuous variables are defined by the size of the offering, measured by the natural logarithm of the gross proceeds $(G P)$, the percentage of the issue offered to external investors (EXT), the abnormal performance of the stock over 200 days prior to the announcement of the issue (PERF) and a variable that measures the proportion of renouncements by blockholders when the firm is closely held (ACTREN). ACTREN is equal to the product of $A C T$ and $R E N$. ACT is equal to 1 if the main shareholder has at least $50 \%$ of the firm. $R E N$ is defined as: $R e n=\frac{\text { blockholdersbefore }- \text { blockholdersafter }}{\text { blockholdersbefore }}$. This 
variable is equal to zero if all the blockholders subscribe to their share allocation. It is positive if some blockholders renounce their allocation: the proportion of the capital that they own decreases after the equity offering. The variable $R E N$ increases in proportion to renouncements by blockholders, but also, if there are some renouncements, to the relative size of the issue.

The qualitative variables included in the model are defined by dummy variables that are equal to one, if the offering is a rights issue (RIG), if the offer is underwritten (GARD), if the offering takes place in the later part of the sample period (1990-1996) (PERIOD), if the firm is issuing shares in order to acquire another firm or to invest in a specified project (USE). ${ }^{21}$

Several other variables were tested but are not reported because of their lack of statistical significance. The subscription price discount has no effect on the wealth effect at the announcement of the offering in France for the total sample, nor for the rights issues sample. This result is similar to the findings of Eckbo and Masulis (1992) in the U.S. and those of Bohren, Eckbo and Michalsen (1997) in Norway. It does not concur with Slovin, Sushka and Lai (2000), who find that the subscription price discount negatively affects the price reaction in the U.K. The other variables, not reported here, are the shareholder guarantee indicator, the stock beta, the stock return standard deviation, the stock residual standard deviation, the size of the issue relative to shares outstanding, the nature of control and the stock's market listing. Results are given in table 8 for the total sample of 219 equity offerings.

\section{[Insert table 8]}

$2162 \%$ of rights offers and $55 \%$ of public offers are specifically for acquisitions and project financing. 


\subsection{Flotation method and offering size}

The indicator variable RIG has a significant negative coefficient. The difference in the market reaction to rights issues and to public offerings is statistically significant after checking for issue characteristics. The announcement effect is greater for rights issues than for public offerings. We confirm the results of our previous section: the differences in announcement price reactions between the two flotation methods are not only due to differences in issue characteristics. Furthermore, the estimated coefficient for the underwriting indicator variable GARD is significantly positive at the $10 \%$ level. Whatever the issuing method, the market reaction is more positive when the offering is underwritten.

The size of the offering has a significantly negative coefficient, indicating a size effect in abnormal returns. The size effect is consistent with a price pressure hypothesis, but also with information-based explanations. Presumably, the more overvalued the equity, the larger the incentive to issue a greater amount of shares. The size effect could also be consistent with a moral hazard / free cash flow hypothesis. This hypothesis is all the more valid as the gross proceeds increases and the use of proceeds is undefined.

\subsection{Prior performance}

The stock runup over 200 days prior to the announcement of the issue, PERF, has a significant negative coefficient, suggesting that the adverse selection effects are more pronounced when the abnormal performance prior to the offering announcement is higher. Asquith and Mullins (1986) document positive abnormal returns in the elevenmonth pre-issue period, which are positively correlated to abnormal returns on the 
announcement date. Masulis and Korwar (1986) find a negative relation with a threemonth prior period. Korajczyck et al. (1990) find a negative relation with a short prior period and a positive relation with a long prior period, while Bohren, Eckbo and Michalsen (1997) find a negative relation with a 40-day prior period. Our results are consistent with the Lucas and McDonald (1990) model: overvalued firms issue equity as soon as the opportunity arises, while undervalued firms postpone the equity issue until the stock price is higher. Thus, on average, the price path prior to the offering for all equity issuers will slope upwards, and the stock price will drop at the issue announcement.

According to table 2, no significant difference appears between underwritten public offerings and standby rights issues in terms of prior performance. Furthermore, the regressions in table 8 show that even after checking for prior performance, public offerings result in a more negative abnormal announcement return. This evidence cannot be explained by the preference of investment bankers for less risky issues, which have not recently experienced a large share price run-up. ${ }^{22}$

\subsection{Period and use of the funds}

The market reaction becomes more negative during the second period of our study (1990-1996). Since 1985, the French market has been gradually deregulated. Bank privatisation in 1986-1987 and the arrival of foreign banks induced more competition in the financial sector. Further, the importance of foreign pension funds in raising capital for French firms grew drastically over the full period of our study. Overall, during this 
period, French firms have become more aware of the necessity of corporate value enhancement, and the market has reacted more rapidly and strongly to negative announcements.

The significant positive value for the coefficient on USE indicates that the simultaneous announcement of the issue purpose (investment or acquisition) reduces information asymmetry between the firm and the investors and therefore the adverse selection borne by investors. The market reaction is about $1 \%$ more positive when the funds are used to acquire another firm or to invest in a specific project (as compared to debt reduction or no indication). This is consistent with a lower moral hazard problem stemming from increasing management's discretionary investment capabilities. According to Mikkelson and Partch (1986), the use of the proceeds has a small effect on price reaction for U.S. firm commitments. Slovin, Sushka and Lai (2000) find a significantly less negative reaction when the proceeds are used for acquisitions only in the case of insured rights issues.

At first glance, the average announcement pattern documented here could be explained by the fact that public offerings are more frequently associated with positive investment announcements, which could partially offset the negative share price effect of the equity announcement. Nevertheless, $61.93 \%$ of the rights offerings are associated with a specified use of proceeds (12.69\% acquisition and $49.24 \%$ investment) compared to $54.55 \%$ for the public offerings (9.09\% acquisition and $45.45 \%$ investment).

Therefore, the use of proceeds cannot really explain the different reactions observed at the time of announcement of the issues.

22 Chen and Ritter (2000) document a clustering of IPO spreads at $7 \%$ whatever the risk of the offering. Investment banks could therefore restrict themselves to less risky issues. But these authors show that for SEOs, there is considerable dispersion in the spreads paid on different deals, depending on their 


\subsection{Ownership structure}

We explore the effects of ownership structure and blockholder rights renouncements on the price reaction at the announcement of an equity offering in France. We find that the share price effect is negatively related to the percentage of the issue offered to outside investors (variable EXT). This result is consistent with results found by Eckbo and Masulis (1992): the adverse selection effect grows with the fraction of the issue offered to external investors. Nevertheless, the initial part of a subscription by external investors can be increased if blockholders renounce their allocation. Our evidence shows that blockholder take-up renouncements when the firm is closely held have a positive effect on the share price response (variable ACTREN, table 8). ${ }^{23} \mathrm{We}$ report the results for the two sub-samples according to the existence of a controlling shareholder (who owns more than 50\%) (see table 9).

\section{[Insert table 9]}

When the main shareholder owns less than $50 \%$ of the capital of the firm, the variable REN has a significantly negative impact on the price reaction on the announcement of the SEO. In this case, our results are consistent with the Eckbo and Masulis (1992) model. Adverse selection increases when blockholders renounce their allocation. But when the main shareholder owns at least $50 \%$ of the capital, the variable REN has a significantly positive impact on the price reaction. Blockholder

characteristics. We cannot explain our results by the choice by investment banks for public offerings of less risky firms.

23 We obtain similar results with other measures of blockholder renouncement when we consider a subsample of firms that are closely held. 
renouncements enhance value by increasing ownership dispersion. Value enhancement may be due to increased liquidity, to better incentives by outside investors to monitor or attenuate conflicts between majority and minority shareholders. It is also interesting to note that the size effect, which is consistent with a moral hazard / free cash flow hypothesis, disappears in the case of majority-controlled firms. The variable PERF has a significant negative coefficient only in the case of majority-controlled firms. The adverse selection effects are more pronounced when there is a controlling shareholder and when abnormal performance prior to the offering announcement is higher. Firms that are not closely held by a controlling shareholder are less subject to adverse selection.

As pointed out by Holmström and Tirole (1993), concentrated ownership reduces monitoring of the firm by stock market participants, thereby reducing the amount of public information available about the firm. This rise in concentration, in turn, could increase bid-ask spreads. For instance, Heflin and Shaw (2000) find that firms with greater blockholder ownership have larger quoted spread, effective spreads, adverse selection spread component, and smaller quoted depths. They argue that potential benefits from blockholder monitoring might be partially offset by reduced liquidity. Kothare (1997) finds that rights issues are associated with an increase in proportional bid-ask spreads, while public underwritten offerings are followed by a decrease in proportional bid-ask spreads. These results are consistent with the different effects of the two flotation methods on the firm's ownership structure. Rights issues can increase ownership concentration, while public offerings decrease it.

Burkart, Gromb and Panunzi (1997) argue that a concentrated ownership structure induces high levels of monitoring and control but makes management less 
active. Ownership concentration involves a trade-off between control and initiative.

Direct evaluation by a large shareholder may reduce the manager's incentives to exert effort.

Further, the French market is characterised by closely held firms. Majority ownership is relatively common. As Schleifer and Vishny (1997) suggest, there may be extra costs to concentrated holdings: large investors represent their own interests and may treat themselves preferentially at the expense of other investors and employees, especially if there is a substantial departure from the one-share-one-vote rule. For most firms in France, there is a one-share-two-votes rule when shares are owned on average for more than 2 to 4 years. Johnson et al. (2000) focus on tunnelling, which is the transfer of resources out of a company to its controlling shareholder. Tunnelling includes asset sales and contracts that are advantageous to the controlling shareholder, loan guarantees and expropriation of corporate opportunities, but also insider trading or other financial transactions that discriminate against minorities. Johnson et al (2000) show that tunnelling occurs more frequently in civil law countries, such as France. In these countries, self-dealing transactions, for instance, are assessed in the light of their conformity with statutes, and not on the basis of their fairness to minorities. A growing body of research suggests that civil-law countries are less protective of minority shareholders than are common-law countries (see La Porta et al., 2000).

Our results show that the favourable ownership dispersion effect offsets the adverse selection effect for firms with an initial concentrated ownership. When the firm is closely held, the announcement of a greater dispersion of share ownership is a favourable information for outside investors, because it will reduce the likelihood of tunnelling and enhance management initiative. Even if the blockholders together still 
own a large part of the shares, minority shareholders may have enhanced power. For instance, in France, charter amendment decisions require a majority of $66.6 \%$ of the voting rights, which is less likely to be reached after an equity offering.

Our evidence can be compared to the results obtained in other countries. According to Bohren, Eckbo and Michalsen (1997), the proportion of common stock held by the 20 largest shareholders has no significant effect on the wealth effect in Norway. But they show that the market reacts more favourably to issues for which the proportion of insiders (board members and the CEO) is greater. Slovin, Sushka and Lai (2000) find a non-linear relation between price reaction and ownership concentration for placings in the U.K. Firms with greater ownership sustain a more favourable price reaction to placings until ownership concentration reaches $40 \%$ of firm shares. For firms with ownership concentration greater than $40 \%$, they find a marginal negative effect. On the other hand, ownership concentration does not affect excess return on insured rights issues in the U.K. According to these authors, U.K. placings entail the sale of the shares to outside investors and lower the ownership concentration. These results are comparable to ours.

In France, the percentage of blockholder renouncements is significantly larger for underwritten public offerings compared to other flotation methods. Two simultaneous positive effects can be observed for public offerings: lower costs of concentrated ownership, and strong underwriter certification. These effects may compensate for the adverse selection effect and may explain the non-negative wealth effect on the announcement of a public offering. They also help to understand why a 
growing proportion of French firms choose to issue shares through the public offering method despite its high flotation costs.

\section{Summary and conclusions}

This paper provides new evidence on the choice of equity flotation method. In France, as in most European countries, a rights issue is the primary flotation method. Our results show that the direct flotation costs of rights issues are significantly lower than the costs of public offerings. The equity financing paradox is confirmed in France: a growing proportion of French firms issuing common stocks choose the relatively expensive public offering method, rather than the rights method.

We find that the abnormal returns around the announcement dates are significantly negative for rights issues, whether of uninsured or standby rights, and negative, but not significantly so, for public offerings. The market reaction is significantly more negative for rights issues when checks are made for the other issuing characteristics. In the French market, the price of public offerings is set several days before the beginning of the issue, and the risk borne by the underwriters is therefore larger than the risk of U.S. firm commitments. These characteristics induce strong underwriter certification and monitoring that may reduce the adverse selection effect of equity offerings and explain the non-negative wealth effect.

We find a significant negative size effect, consistent with a price pressure hypothesis. The price reaction is negatively related to the stock price performance prior to the offering announcement. The market reaction is more positive when the funds are 
used for an acquisition or an investment, which is consistent with a lower adverse selection effect.

We explore the effects of ownership structure and blockholder renouncements on the price reaction at the announcement of an equity offering. We show that for firms without a controlling shareholder, the adverse selection effect increases with the fraction of the issue not taken up by current shareholders, as predicted by Eckbo and Masulis (1992). But for closely controlled firms, our evidence shows that blockholder take-up renouncements have a positive effect on the share price response. Blockholder renouncements imply lower shareholder concentration. This lower concentration enhances value by attenuating conflicts between majority and minority shareholders and, in particular,by reducing the likelihood of tunnelling. The favourable ownership dispersion effect mitigates the adverse selection effect for firms with an initialy large concentrated ownership. Finally, the larger flotation costs associated with public offerings in France may be offset by the less negative wealth effect at the announcement of the issue. This result helps to understand why a growing proportion of French firms are choosing the public offering method.

\section{REFERENCES}

Asquith, P. and D.W. Mullins, 1986, Equity Issues and Offering Dilution, Journal of Financial Economics 15, 61-89.

Bohren O., Eckbo B. and D. Michalsen, 1997, Why Underwrite Rights Offerings? Some New Evidence, Journal of Financial Economics 46, 223-261. 
Burkart M., Gromb D. and F. Panunzi, 1997, Large Shareholders, Monitoring, and the Value of the Firm, Quarterly Journal of Economics, 112, 693-728.

Chen H.C. and J.R. Ritter, 2000, The Seven Percent Solution, Journal of Finance, 55, 1105-1131.

Cooney J.W., Kato H., and J.S. Schallheim, 1997, Underwriter Certification and Japanese Seasoned Equity Issues, Working paper, University of Utah.

Dimson, E., 1979, Risk Measurement when Shares are Subject to Infrequent Trading, Journal of Financial Economics 7, 197-226.

Eckbo B.E. and R.W. Masulis, 1992, Adverse Selection and the Rights Offer Paradox, Journal of Financial Economics 32, 293-332.

Eckbo, B.E. and R.W. Masulis, 1995, Seasoned Equity Offerings: a survey, in R. Jarrow et al. (ed.), Handbooks in OR\&MS 9, Elsevier Science, 1017-1072.

Fowler, D.J. and C.H. Rorke, 1983, Risk Measurement when Shares are Subject to Infrequent Trading, Comment, Journal of Financial Economics 12, 279-283.

Gebhardt, G. and S. Heiden, 1998, Explaining Capital Market Reactions to Equity Offers by German Companies, Working paper, University of Frankfurt.

Hansen, R.S., 1988, The Demise of the Rights Issue, Review of Financial Studies 1, 289-309.

Hansen R.S., and J. Pinkerton, 1982, Direct Equity Financing: A Resolution of a Paradox, Journal of Finance 37, 651-665.

Heflin F. and K.W. Shaw, 2000, Blockholder Ownership and Market Liquidity, Journal of Financial and Quantitative Analysis, 35, 621-633.

Hietala, P. and T. Löyttyniemi, 1991, An Implicit Dividend Increase in Rights Issues: Theory and Evidence, Working paper, Insead. 
Holmström B., and J. Tirole, 1993, Market Liquidity and Performance Monitoring, Journal of Political Economy 101, 678-709.

Johnson S., R. La Porta, F. Lopez-de-Silanes and A. Schleifer, 2000, Tunneling, American Economic Review, Papers and Proceedings, 90, 22-27.

Kang, J.K. and R.M. Stulz, 1996, How Different is Japanese Corporate Finance? An Investigation of the Information Content of New Equity Issues, Review of Financial Studies 9, 109-139.

Korajczyk, R.A., D.J. Lucas and R.L. McDonald, 1990, Understanding Stock Price Behavior around the Time of Equity Issues, in Asymmetric information, corporate finance and investment, R.G. Hubbard ed., University of Chicago Press.

Korajczyk, R.A., D.J. Lucas and R.L. McDonald, 1991, The Effect of Information Releases on the Pricing and Timing of Equity Issues, Review of Financial Studies 4, 685-708.

Korajczyk, R.A., D.J. Lucas and R.L. McDonald, 1992, Equity Issues with TimeVarying Asymmetric Information, Journal of Financial and Quantitative Analysis 27, 397-417.

Kothare M., 1997, The Effect of Equity Issues on Ownership Structure and Stock Liquidity: A Comparison of Rights and Public Offerings, Journal of Financial Economics 43, 131-148.

La Porta R., Lopez-de-Silanes F., Schleifer A., and R. Vishny, 2000, Investor protection and Corporate Governance, Journal of Financial Economics, 58, 3-27.

Lease, R.C., R.W. Masulis and J.R. Page, 1991, An Investigation of Market Microstructure Impacts on Event Study Returns, Journal of Finance 46, 1523-1536. 
Loderer, C.F. and H. Zimmerman, 1987, Stock Offerings in a Different Institutional Setting: the Swiss Case, Journal of Banking and Finance 12, 353-377.

Lucas, D.J. and R.L. McDonald, 1990, Equity Issues and Stock Price Dynamics, Journal of Finance 45, 1019-1043.

Masulis, R.W. and A.N. Korwar, 1986, Seasoned Equity Offerings: an Empirical Investigation, Journal of Financial Economics 15, 91-118.

Mikkelson, W.H. and M.M. Partch, 1988, Withdrawn Security Offerings, Journal of Financial and Quantitative Analysis 23, 119-133.

Schleifer, A. and R.W. Vishny, 1997, A Survey of Corporate Governance, Journal of Finance 52, 737-784.

Scholes, M. and J.T. Williams, 1977, Estimating Betas from Non-Synchronous Data, Journal of Financial Economics 5, 309-327.

Singh, A.K., 1997, Layoffs and Underwritten Rights Offers, Journal of Financial Economics 43, 105-130.

Slovin M.B., Sushka M.E., and W. Lai, 2000, Alternative Flotation Methods, Adverse Selection, and Ownership Structure: Evidence from Seasoned Equity Issuance in the UK, Journal of Financial Economics, 57, 157-190.

Smith, C.W., 1977, Alternative Methods for Raising Capital: Rights versus Underwritten Offerings, Journal of Financial Economics 5, 273-307. White, H., 1980, A Heteroskedasticity-Consistent Covariance Matrix Estimator and a Direct Test for Heteroskedasticity, Econometrica 48, 817-838. 
Figure 1 - Time-line of dates used in seasoned equity issues in France

\begin{tabular}{ccccc}
\hline H1 & Wl & Wl & 丩b \\
Board Meeting & “Européenne des données ” Visa COB & BALO & Issue \\
CA & EDD & CD & BD & ID
\end{tabular}

Note: This figure shows the different dates of the process of seasoned equity issues in France, from the Board Meeting decision (CA) to the issue date (ID). The BALO date (BD) is the legal date of announcement. The first institutional announcement of offering information generally comes in the registration statement filed with the COB (CD). The “Européenne des données" date (EDD) corresponds to the first mention of the offerings in the press. 
Table 1 - Equity issues in France from 1986 to 1996

\begin{tabular}{ccccc}
\hline Year & Uninsured Rights & $\begin{array}{c}\text { Rights with standby } \\
\text { underwriting }\end{array}$ & Public offerings & Total \\
\hline 1986 & 11 & 29 & 3 & 43 \\
1987 & 11 & 25 & 2 & 38 \\
1988 & 4 & 10 & 0 & 14 \\
1989 & 10 & 18 & 1 & 29 \\
1990 & 8 & 15 & 3 & 26 \\
1991 & 6 & 17 & 8 & 31 \\
1992 & 1 & 2 & 2 & 5 \\
1993 & 0 & 3 & 1 & 4 \\
1994 & 5 & 12 & 1 & 18 \\
1995 & 0 & 2 & 0 & 2 \\
1996 & 1 & 7 & 1 & 9 \\
\hline Total & 57 & 140 & 22 & 219 \\
\hline
\end{tabular}

Note: The data are from COB annual reports. Uninsured rights are rights offerings without bank standby underwriting. Public offerings are seasoned equity issues without rights. 
Table 2 - Mean (median) characteristics of 219 equity issues on the French Stock Exchange from 1986 to 1996

\begin{tabular}{|c|c|c|c|c|c|}
\hline & $\begin{array}{l}\text { Uninsured } \\
\text { rights }\end{array}$ & $\begin{array}{c}\text { Standby rights } \\
\text { offerings }\end{array}$ & Uninsured public offerings & $\begin{array}{l}\text { Underwritten } \\
\text { public offerings }\end{array}$ & All offers \\
\hline Number of observations & 57 & 140 & 4 & 18 & 219 \\
\hline Gross proceeds (FF Millions) & $\begin{array}{l}217.86 \\
(96.98)\end{array}$ & $\begin{array}{l}405.32 \\
(139.06)\end{array}$ & $\begin{array}{l}670.83 \\
(531.52)\end{array}$ & $\begin{array}{l}1367.97 \\
(442.5)\end{array}$ & $\begin{array}{l}440.5 \\
(118.45)\end{array}$ \\
\hline Subscription price / common stock price ${ }^{a}$ & $\begin{array}{l}0.78 \\
(0.78)\end{array}$ & $\begin{array}{l}0.78 \\
(0.79) \\
\end{array}$ & $\begin{array}{l}0.98 \\
(0.98) \\
\end{array}$ & $\begin{array}{l}0.94 \\
(0.97) \\
\end{array}$ & $\begin{array}{l}0.80 \\
(0.8) \\
\end{array}$ \\
\hline Market value of equity (FF Millions) $^{b}$ & $\begin{array}{l}1223.84 \\
(317.8)\end{array}$ & $\begin{array}{l}2875.59 \\
(610.52) \\
\end{array}$ & $\begin{array}{l}3824.45 \\
(2685.75)\end{array}$ & $\begin{array}{l}10636.5 \\
(1389.98)\end{array}$ & $\begin{array}{l}3066.33 \\
(486.79)\end{array}$ \\
\hline Percentage of change in shares $(\%)^{c}$ & $\begin{array}{l}24.33 \\
(20.0) \\
\end{array}$ & $\begin{array}{l}24.03 \\
(20.0) \\
\end{array}$ & $\begin{array}{l}21.75 \\
(17.0) \\
\end{array}$ & $\begin{array}{l}16.83 \\
(19.0) \\
\end{array}$ & $\begin{array}{l}23.47 \\
(20.0) \\
\end{array}$ \\
\hline Underwriter guarantee (\%) & - & $\begin{array}{l}84.88 \\
(100)\end{array}$ & - & $\begin{array}{l}72.9 \\
(100)\end{array}$ & $\begin{array}{l}60.25 \\
(100)\end{array}$ \\
\hline $\begin{array}{l}\text { Number of offerings with an international } \\
\text { part }\end{array}$ & 0 & 0 & 0 & 9 & 9 \\
\hline Prior performance $(\%)^{d}$ & $\begin{array}{l}23.18 \\
(15.78) \\
\end{array}$ & $\begin{array}{l}27.87 \\
(24.78) \\
\end{array}$ & $\begin{array}{l}-10.3 \\
(-9.45) \\
\end{array}$ & $\begin{array}{l}23.48 \\
(17.31) \\
\end{array}$ & $\begin{array}{l}25.59 \\
(20.44) \\
\end{array}$ \\
\hline Underwriting costs/ gross proceeds (\%) & $\begin{array}{l}1.27 \\
(0.85)\end{array}$ & $\begin{array}{l}1.79 \\
(1.67)\end{array}$ & $\begin{array}{l}0.78 \\
(0.74)\end{array}$ & $\begin{array}{l}2.53 \\
(2.61)\end{array}$ & $\begin{array}{l}1.7 \\
(1.5)\end{array}$ \\
\hline $\begin{array}{l}\text { Legal and administrative costs/ gross } \\
\text { proceeds (\%) }\end{array}$ & $\begin{array}{l}0.36 \\
(0.24)\end{array}$ & $\begin{array}{l}0.39 \\
(0.2)\end{array}$ & $\begin{array}{l}0.15 \\
(0.11)\end{array}$ & $\begin{array}{l}0.36 \\
(0.26)\end{array}$ & $\begin{array}{l}0.37 \\
(0.23)\end{array}$ \\
\hline $\begin{array}{l}\text { Underwriting costs / public gross proceeds } \\
(\%) \mathrm{e}\end{array}$ & $\begin{array}{l}6.62 \\
(3.93)\end{array}$ & $\begin{array}{l}5.91 \\
(4.15)\end{array}$ & $\begin{array}{l}2.74 \\
(3.13)\end{array}$ & $\begin{array}{l}7.79 \\
(5.97)\end{array}$ & $\begin{array}{l}6.19 \\
(4.14)\end{array}$ \\
\hline $\begin{array}{l}\text { Legal and administrative costs/ public } \\
\text { gross proceeds (\%) }\end{array}$ & $\begin{array}{l}1.84 \\
(0.85) \\
\end{array}$ & $\begin{array}{l}1.39 \\
(0.57) \\
\end{array}$ & $\begin{array}{l}0.82 \\
(0.42) \\
\end{array}$ & $\begin{array}{l}1.15 \\
(0.7) \\
\end{array}$ & $\begin{array}{l}1.48 \\
(0.73) \\
\end{array}$ \\
\hline
\end{tabular}


a. The ratio of subscription price over common stock price is measured by using the price of the stock just before the first date of announcement of the issue.

b. The market value of equity is measured by multiplying the stock price just before the announcement of the issue by the number of shares available on that date.

c. The percentage of change in the number of shares is calculated by $\frac{\text { Number of shares issued }}{\text { Number of old shares }+ \text { Number of shares issued }}$.

d. Prior performance is calculated according to the mean of abnormal returns over 200 days just before the announcement date : $\mathrm{RAM}_{\mathrm{i}}=\frac{1}{200} \sum_{\mathrm{t}=-1}^{-200} \mathrm{RA}_{\mathrm{it}}$.

e. Public gross proceeds is the part of the gross proceeds that is not taken up by the shareholders owning more than $5 \%$ of the shares. 
Table 3 - Mean (median) share ownership, precommitments and characteristics of blockholder take-up renouncements

\begin{tabular}{|c|c|c|c|c|c|}
\hline & $\begin{array}{l}\text { Uninsured } \\
\text { rights }\end{array}$ & $\begin{array}{c}\text { Standby rights } \\
\text { offerings }\end{array}$ & $\begin{array}{c}\text { Uninsured } \\
\text { public offerings }\end{array}$ & $\begin{array}{c}\text { Underwritten } \\
\text { public offerings }\end{array}$ & All offers \\
\hline Number of observations & 57 & 140 & 4 & 18 & 219 \\
\hline Percentage of shares held by the main shareholder before the offering & $\begin{array}{c}50.73 \\
(50.60)\end{array}$ & $\begin{array}{c}45.72 \\
(48.00)\end{array}$ & $\begin{array}{c}54.54 \\
(50.13)\end{array}$ & $\begin{array}{c}29.78 \\
(26.94)\end{array}$ & $\begin{array}{c}45.88 \\
(47.86)\end{array}$ \\
\hline Percentage of shares held by blockholders before the offering & $\begin{array}{c}72.48 \\
(76.56) \\
\end{array}$ & $\begin{array}{c}62.17 \\
(65.90) \\
\end{array}$ & $\begin{array}{c}70.18 \\
(74.56) \\
\end{array}$ & $\begin{array}{c}54.50 \\
(65.79) \\
\end{array}$ & $\begin{array}{c}64.38 \\
(69.64) \\
\end{array}$ \\
\hline \multicolumn{6}{|c|}{ Identity of the largest blockholder (percentage of the total number of offerings for each flotation method) } \\
\hline No blockholder & 1.8 & 3.6 & 0 & 11.1 & 3.7 \\
\hline Financial institution & 35.1 & 37.1 & 50.0 & 27.8 & 36.1 \\
\hline Family or individual investor & 10.5 & 17.9 & 25.0 & 22.2 & 16.4 \\
\hline Corporate blockholder & 52.6 & 41.4 & 25.0 & 16.7 & 42.0 \\
\hline State & 0 & 0 & 0 & 22.2 & 1.8 \\
\hline Percentage of issues with major blockholder subscription guarantee & 49.12 & 20.71 & 100 & 27.78 & 30.14 \\
\hline Percentage of the offering guaranted by the major blockholders & 96.79 & 62.87 & 86.08 & 72.16 & 79.37 \\
\hline (excluding firms with zero shareholder guarantee) & $(100)$ & $(60)$ & $(100)$ & $(75)$ & $(90.70)$ \\
\hline Percentage of issues with blockholder take-up renouncements & 26.3 & 28.6 & 50.0 & 33.3 & 28.8 \\
\hline Share allocation not taken up by blockholders (\%) & 39.47 & 32.23 & 19.06 & 62.53 & 36.42 \\
\hline (excluding firms with zero blockholderrenouncements) & $(24.67)$ & $(30.03)$ & $(19.06)$ & $(65.31)$ & $(31.33)$ \\
\hline \multirow[t]{2}{*}{ Percentage of the issue offered to external investors } & 37.90 & 46.94 & 39.35 & 62.90 & 45.73 \\
\hline & $(31.43)$ & $(44.30)$ & $(42.15)$ & $(57.80)$ & $(41.64)$ \\
\hline
\end{tabular}

Note: Blockholders are the shareholders whose names are included in the registration statement filed with the COB (shareholders who own more than $5 \%$ of the shares). The means and medians of the percentage of shareholder guarantee exclude firms with zero shareholder guarantee. The means and medians of share allocation not taken up by blockholders exclude firms with zero blockholder renouncements. 
Table 4 - Cross-sectional regression model of flotation costs for 219 equity issues between 1986 and 1996

\begin{tabular}{lccc}
\hline Variable & Model l & Model 2 & Model 3 \\
\hline Constant & $\mathbf{4 . 1 6 5 * * *}$ & $\mathbf{3 . 1 5 6 8 * * *}$ & $\mathbf{3 . 4 2 9 4 * * *}$ \\
& {$[\mathbf{8 . 0 5}]$} & {$[\mathbf{6 . 3 9 ]}$} & {$[\mathbf{6 . 6 ]}$} \\
RIG & $\mathbf{- 0 . 9 7 2 5 * * *}$ & $\mathbf{- 0 . 6 6 0 9 * * *}$ & $\mathbf{- 0 . 7 9 6 7 * * *}$ \\
& {$[-3.7]$} & {$[-3.53]$} & {$[-4.22]$} \\
Ln $(G P)$ & $\mathbf{- 0 . 3 9 6 8 * * *}$ & $\mathbf{- 0 . 4 1 7 3 * * *}$ & $\mathbf{- 0 . 4 0 3 7 * * *}$ \\
& {$[-5.3]$} & {$[-6.25]$} & {$[-6.25]$} \\
GAR & $\mathbf{0 . 0 1 1 7 * * *}$ & $\mathbf{0 . 0 0 8 2 * * *}$ & $\mathbf{0 . 0 0 8 * * *}$ \\
& {$[6.45]$} & {$[4.7]$} & {$[4.66]$} \\
EXT & & $\mathbf{0 . 0 2 2 9 * * *}$ & $\mathbf{0 . 0 2 2 3 * * *}$ \\
& & {$[7.39]$} & {$[7.14]$} \\
PERIOD & & & $\mathbf{- 0 . 4 2 5 3 * * *}$ \\
& & & {$[-2.88]$} \\
Adj R ${ }^{2}$ & $\mathbf{0 . 2 5 9}$ & $\mathbf{0 . 4 1 5}$ & $\mathbf{0 . 4 3 2}$ \\
\hline
\end{tabular}

Note: The dependant variable is the total cost of the issue divided by the gross proceeds $(G P)$, in percentage. $R I G=$ Indicator value of 1 if it is a rights issue. $\operatorname{Ln}(G P)$ designates the size of the issue (logarithm of the gross proceeds). GAR = underwritten percentage of the offer. EXT is the percentage of the issue not taken up by blockholders. PERIOD is a dummy variable that equals one when the offering takes place in the second period (1990-1996), and zero otherwise. *, **,*** denote significance of the test at the 0.1, 0.05 and 0.01 levels respectively. Tests in brackets are based on White's (1980) heteroskedastic consistent variance covariance matrices. 
Table 5 - Calendar of operations

\begin{tabular}{cccccc}
\hline Interval & $\begin{array}{c}\text { Uninsured } \\
\text { rights }\end{array}$ & $\begin{array}{c}\text { Standby } \\
\text { rights } \\
\text { offerings }\end{array}$ & $\begin{array}{c}\text { Uninsured } \\
\text { public } \\
\text { offerings }\end{array}$ & $\begin{array}{c}\text { Underwritten } \\
\text { public } \\
\text { offerings }\end{array}$ & All offers \\
\hline EDD->BD & 6.1 & 7.09 & 2.5 & 14.13 & 9.81 \\
& $(10.19)$ & $(12.28)$ & $(0.5)$ & $(17.04)$ & $(25.65)$ \\
CA->CD & {$[0]$} & {$[1]$} & {$[2]$} & {$[3]$} & {$[1]$} \\
& 14.61 & 11.09 & 2.25 & 5.67 & 11.39 \\
& $(20.66)$ & $(20.92)$ & $(2.28)$ & $(13.55)$ & $(20.31)$ \\
COB->BD & {$[9]$} & {$[5]$} & {$[1]$} & {$[1]$} & {$[4]$} \\
& 4.79 & 4.87 & 3.5 & 3.61 & 4.72 \\
COB-> ID & $(2.97)$ & $(7.63)$ & $(1.12)$ & $(2.11)$ & $(6.33)$ \\
& {$[4]$} & {$[3]$} & {$[3]$} & {$[3]$} & {$[3]$} \\
& 9.6 & 9.81 & 3.5 & 4.44 & 9.2 \\
Balo->ID & $(3.4)$ & $(7.75)$ & $(1.12)$ & $(3.74)$ & $(6.73)$ \\
& {$[8]$} & {$[8]$} & {$[3]$} & {$[3]$} & {$[8]$} \\
& 4.81 & 4.94 & 0 & 1.19 & 4.54 \\
ID ->END & $(1.59)$ & $(1.16)$ & $(0)$ & $(2.86)$ & $(1.86)$ \\
& {$[5]$} & {$[5]$} & {$[0]$} & {$[0]$} & {$[5]$} \\
& 15.27 & 14.85 & 11.5 & 7.53 & 14.31 \\
& $(2.52)$ & $(3.21)$ & $(5.02)$ & $(4.75)$ & $(3.84)$ \\
& {$[15]$} & {$[15]$} & {$[9]$} & {$[9]$} & {$[15]$} \\
\hline
\end{tabular}

Notes: Figures are trading days. They represent the means, the standard deviations (in parentheses) and the medians (in brackets) of the number of trading days between the two dates indicated in the left-hand column:

- $\quad$ from The “Européenne des données" date (EDD) (first mention of an offering in the press) to the BALO date (BD) (the legal date of announcement) ;

- $\quad$ from the Board Meeting decision (CA) to the BALO date (BD);

- the first institutional announcement of offering information that generally comes in the registration statement filed with the COB (CD) to the issue date (ID);

- $\quad$ from the BALO date (BD) to the issue date (ID);

- $\quad$ from the issue date (ID) to the end of the subscription period (END); 
Table 6 - Price impact on the announcement date

\begin{tabular}{|c|c|c|c|c|c|}
\hline & \begin{tabular}{|l} 
Sample \\
size
\end{tabular} & \begin{tabular}{|l|} 
Two-day \\
return
\end{tabular} & Test & \begin{tabular}{|l|}
$\begin{array}{l}\text { Five-day } \\
\text { return }\end{array}$ \\
\end{tabular} & Test \\
\hline \multicolumn{6}{|l|}{ Panel A. 1986-1996 period } \\
\hline \multicolumn{6}{|l|}{ Rights offerings } \\
\hline Uninsured rights & 57 & $-1.11 \% * * *$ & -2.96 & $-1.73 \% * * *$ & -2.68 \\
\hline Standby rights & 140 & $-0.74 \% * *$ & -2.07 & $-1.1 \% *$ & -1.78 \\
\hline \multicolumn{6}{|l|}{ Public offerings } \\
\hline All public offerings & 22 & $-0.42 \%$ & -0.62 & $-1.44 \%$ & -1.23 \\
\hline Underwritten public offerings & 18 & $-0.33 \%$ & -0.43 & $-1.35 \%$ & -1.02 \\
\hline \multicolumn{6}{|l|}{ Panel B. 1990-1996 period } \\
\hline \multicolumn{6}{|l|}{ Rights offerings } \\
\hline Uninsured rights & 20 & $-2.84 \% * * *$ & -4.47 & $-2.58 \% * *$ & -2.35 \\
\hline Standby rights & 57 & $-1.28 \% * * *$ & -3.51 & $-1.44 \% * *$ & -2.28 \\
\hline \multicolumn{6}{|l|}{ Public offerings } \\
\hline All public offerings & 16 & $-0.33 \%$ & -0.46 & $-1.2 \%$ & -0.97 \\
\hline Underwritten public offerings & 12 & $-0.17 \%$ & -0.2 & $-0.98 \%$ & -0.66 \\
\hline
\end{tabular}

Note: The event date is the first date of announcement (either EDD or COB) of seasoned equity offerings by French firms over the 1986-1996 period. Similar results have been found when considering each of the two dates separately. The mean excess returns, calculated by using Dimson's method, are cumulated over the period from 0 to 1 day and from 0 to 5 days. The parametric tests are the tests calculated over the cumulative mean abnormal returns, $T C_{t p s}$. Let $n b j$ be the number of cumulative abnormal returns, $R A M C$ the cumulative mean abnormal return over nbj days, $\sigma(R A M)$ the time-series standarddeviation over the estimation period ; $T C_{t p s}$ can be estimated by $T C_{t p s}=\frac{R A M C}{\sqrt{n b j} \sigma(R A M)} . *, * *, * * *$ denote significance of the test at the $0.1,0.05$ and 0.01 levels respectively. 
Table 7 - Price impact on the issue date

\begin{tabular}{|c|c|c|c|c|c|c|c|}
\hline & $\begin{array}{l}\begin{array}{l}\text { Sample } \\
\text { size }\end{array} \\
\end{array}$ & $\begin{array}{l}\text { Two-day } \\
\text { return }\end{array}$ & Test & $\begin{array}{l}\text { Five-day } \\
\text { return }\end{array}$ & Test & $\begin{array}{l}\text { Twenty-day } \\
\text { return }\end{array}$ & Test \\
\hline \multicolumn{8}{|l|}{$\underline{\text { Rights offerings }}$} \\
\hline Uninsured rights & 57 & $-0.59 \% *$ & -1.64 & $-2.6 \% * * *$ & -4.14 & $-5.92 \% * * *$ & -5.04 \\
\hline Standby rights & 140 & $-0.33 \%$ & -0.96 & $-1.56 \% * * *$ & -2.61 & $-4.06 \% * * *$ & -3.62 \\
\hline \multicolumn{8}{|l|}{ Public offerings } \\
\hline All public offerings & 22 & $-1.18 \% * *$ & -2 & $-1.86 \% *$ & -1.82 & $-5.76 \% * * *$ & -3.01 \\
\hline Underwritten public offerings & 18 & $-1.2 \% *$ & -1.76 & $-1.39 \%$ & -1.18 & $-6.1 \% * * *$ & -2.77 \\
\hline
\end{tabular}

Note: The event date is the offering date of seasoned equity offerings by French firms over the 1986-1996 period. The mean excess returns, calculated by using Dimson's method, are cumulated over the period from 0 to 1 day, from 0 to 5 days and from 0 to 20 days. The parametric tests represent the tests calculated over the cumulative mean abnormal returns, $T C_{t p s}$. Let $n b j$ be the number of cumulative abnormal returns, RAMC the cumulative mean abnormal return over nbj days, $\sigma(R A M)$ the timeseries standard-deviation over the estimation period ; $T C_{t p s}$ can be estimated by $T C_{t p s}=\frac{R A M C}{\sqrt{n b j} \sigma(R A M)}$. $*, * *, * * *$ denote significance of the test at the $0.1,0.05$ and 0.01 levels respectively. 
Table 8 - Cross-sectional regression model on the announcement date for 219 equity issues from 1986 to 1996

\begin{tabular}{|c|c|c|c|c|c|c|}
\hline Variable & Model 1 & Model 2 & Model 3 & Model 4 & Model 5 & Model 6 \\
\hline Constant & $\begin{array}{c}0.0304 \\
{[2.95]^{* * *}}\end{array}$ & $\begin{array}{c}0.0387 \\
{[3.46]^{* * *}}\end{array}$ & $\begin{array}{c}\mathbf{0 . 0 3 6 6} \\
{[3.34]^{* * *}}\end{array}$ & $\begin{array}{c}0.0367 \\
{[3.19]^{* * *}}\end{array}$ & $\begin{array}{c}0.0471 \\
{[3.49]^{* * *}}\end{array}$ & $\begin{array}{c}0.0432 \\
{[3.38]^{* * *}}\end{array}$ \\
\hline $\operatorname{Ln}(G P)$ & $\begin{array}{c}-0.0045 \\
{[-3.25]^{* * *}}\end{array}$ & $\begin{array}{c}-0.0044 \\
{[-3.21]^{* * *}}\end{array}$ & $\begin{array}{c}-0.0049 \\
{[-3.5]^{* * *}}\end{array}$ & $\begin{array}{c}-0.0053 \\
{[-3.57]^{* * *}}\end{array}$ & $\begin{array}{c}-0.0054 \\
{[-3.62]^{* * *}}\end{array}$ & $\begin{array}{c}-0.0059 \\
{[-3.81]^{* * *}}\end{array}$ \\
\hline PERIOD & $\begin{array}{c}-0.0114 \\
{[-2.2]^{* *}}\end{array}$ & $\begin{array}{c}-0.0171 \\
{[-2.88]^{* * *}}\end{array}$ & $\begin{array}{c}-0.0179 \\
{[-3.03]^{* * *}}\end{array}$ & $\begin{array}{c}-\mathbf{0 . 0 1 9} \\
{[-3.13]^{* * *}}\end{array}$ & $\begin{array}{c}-0.0196 \\
{[-3.25]^{* *}}\end{array}$ & $\begin{array}{c}-\mathbf{0 . 0 2 0 1} \\
{[-3.36]^{* * *}}\end{array}$ \\
\hline RIG & $\begin{array}{c}-0.013 \\
{[-1.99]^{* *}}\end{array}$ & $\begin{array}{c}-0.0134 \\
{[-2.06]^{* *}}\end{array}$ & $\begin{array}{c}-0.015 \\
{[-2.26]^{* *}}\end{array}$ & $\begin{array}{c}-0.0139 \\
{[-1.98]^{* *}}\end{array}$ & $\begin{array}{c}-0.0159 \\
{[-2.22]^{* *}}\end{array}$ & $\begin{array}{c}-0.0159 \\
{[-2.26]^{* *}}\end{array}$ \\
\hline$P E R F$ & & $\begin{array}{c}-0.0224 \\
{[-2.77]^{* * *}}\end{array}$ & $\begin{array}{c}-0.0238 \\
{[-2.93]^{* * *}}\end{array}$ & $\begin{array}{l}-0.0257 \\
{[-3]^{* * *}}\end{array}$ & $\begin{array}{c}-0.0233 \\
{[-2.74]^{* * *}}\end{array}$ & $\begin{array}{c}-0.0239 \\
{[-2.82]^{* * *}}\end{array}$ \\
\hline USE & & & $\begin{array}{c}0.0117 \\
{[2.15]^{* *}}\end{array}$ & $\begin{array}{c}0.0119 \\
{[2.16]^{* *}}\end{array}$ & $\begin{array}{c}0.0124 \\
{[2.25]^{* * *}}\end{array}$ & $\begin{array}{c}0.0127 \\
{[2.31]^{* *}}\end{array}$ \\
\hline ACTREN & & & & $\begin{array}{c}0.0541 \\
{[2.86]^{* * *}}\end{array}$ & $\begin{array}{c}0.0733 \\
{[2.93]^{* * *}}\end{array}$ & $\begin{array}{c}0.0774 \\
{[2.99]^{* * *}}\end{array}$ \\
\hline$E X T$ & & & & & $\begin{array}{l}-0.0002 \\
{[-1.78]^{*}}\end{array}$ & $\begin{array}{c}-0.0002 \\
{[-2.11]^{* *}}\end{array}$ \\
\hline GARD & & & & & & $\begin{array}{l}0.0111 \\
{[1.87]^{*}}\end{array}$ \\
\hline Adj $R^{2}$ & 0.05 & 0.09 & 0.11 & 0.12 & 0.133 & 0.147 \\
\hline
\end{tabular}

Note: This table presents the cross-sectional regression model explaining the two-day cumulative excess returns on announcement of seasoned equity offerings in France from 1986 to 1996. The event date is the first announcement date between EDD and COB. The dependant variable is the two-day cumulative excess return from the announcement. The least squares regression models are developed, using hypothesis tests based on consistent estimates of covariance matrices allowing for heteroskedasticity, as in White (1980). *, **, *** denote significance of the test at the $0.1,0.05$ and 0.01 levels respectively: t-statistics are in brackets.

The continuous variables are the following:

- $\quad \operatorname{Ln}(G P)$ is the logarithm of the gross proceeds ;

- $\quad E X T$ is the percentage of the issue not taken up by blockholders;

- PERF designates the long-run abnormal performance of the firm over 200 days prior to the announcement of the issue;

- ACTREN is equal to the product of ACT and REN. ACT is equal to 1 if the main shareholder has at least $50 \%$ of the firm. $R E N$ is defined by: Ren $=\frac{\text { blockholdersbefore }- \text { blockholdersafter }}{\text { blockholdersbefore }}$.

The qualitative variables are as follows:

$R I G$ is an indicator value that has a value of 1 if the offer is a rights issue ;

- $\quad G A R D$ is a dummy variable that equals one when the offer is underwritten;

- $\quad$ PERIOD is a dummy variable that equals one when the offering takes place in the second period (1990-1996);

- USE is an indicator value that equals 1 if the firm issues shares in order to acquire another firm or to invest in a specified project. 
Table 9 - Cross-sectional regression model on the announcement date for two subsamples of seasoned equity offerings

\begin{tabular}{|c|c|c|}
\hline \multirow[t]{2}{*}{ Variable } & Panel A & Panel B \\
\hline & $\begin{array}{l}\text { Majority- } \\
\text { controlled } \\
\text { firms }\end{array}$ & Other firms \\
\hline Constant & $\begin{array}{c}0.0221 \\
{[2.09]^{* *}}\end{array}$ & $\begin{array}{c}0.0305 \\
{[2.55]^{* *}}\end{array}$ \\
\hline $\operatorname{Ln}(G P)$ & $\begin{array}{c}-0.0023 \\
{[-1.24]}\end{array}$ & $\begin{array}{c}-0.006 \\
{[-2.66]^{* * *}}\end{array}$ \\
\hline PERIOD & $\begin{array}{c}-0.0167 \\
{[-2.65]^{* * *}}\end{array}$ & $\begin{array}{c}-0.0169 \\
{[-1.75]^{*}}\end{array}$ \\
\hline$P E R F$ & $\begin{array}{c}-0.0281 \\
{[-4.21]^{* * *}}\end{array}$ & $\begin{array}{c}-0.0229 \\
{[-1.41]}\end{array}$ \\
\hline REN & $\begin{array}{c}0.041 \\
{[2.23]^{* *}}\end{array}$ & $\begin{array}{c}-0.1224 \\
{[-1.79]^{*}}\end{array}$ \\
\hline Adj $R^{2}$ & 0.122 & 0.105 \\
\hline
\end{tabular}

Note: This table presents the cross-sectional regression model explaining the two-day cumulative excess returns on announcement of seasoned equity offerings in France from 1986 to 1996. The event date is the first announcement date between EDD and COB. The dependant variable is the two-day cumulative excess return from the announcement. The least squares regression models are developed, using hypothesis tests based on consistent estimates of covariance matrices allowing for heteroskedasticity, as in White (1980). *, **, *** denote significance of the test at the $0.1,0.05$ and 0.01 levels respectively: t-statistics are in brackets. Firms with a first shareholder who owns more than $50 \%$ of the capital are designated as majority-controlled firms.

The continuous variables are as follows:

- $\quad \operatorname{Ln}(G P)$ is the logarithm of the gross proceeds ;

- PERF designates the long-run abnormal performance of the firm over 200 days prior to the announcement of the issue;

- REN is defined by: Ren $=\frac{\text { blockholdersbefore }- \text { blockholdersafter }}{\text { blockholdersbefore }}$.

The qualitative variable is as follows:

- PERIOD is a dummy variable that equals one when the offering takes place in the second period (1990-1996); 